\title{
Development of Physics Learning Tools Contains Integration of Qur'an Values
}

\author{
Sriatun $^{1}$, Suharto Linuwih ${ }^{2}$, Sulhadi $^{3}$, Aninditya $^{4}$ \\ ${ }_{1,2,3,4}$ Graduate School, Universitas Negeri Semarang, Indonesia \\ Corresponding email: sriyatum@gmail.com
}

\begin{abstract}
This research develops product in the form of a physics learning device containing Quranic value integration to instilling analytical thinking on vocational students. The study used Research and Development (R\&D) design. The feasibility of the learning tool is done by the material experts, integration experts, learning experts, and physics teachers. The results of data analysis indicate that the learning tool that has been developed is considered very good and feasible to be used as teaching material in the learning of SMK class $\mathrm{X}$ on temperature and heat subject.
\end{abstract}

Keywords: Quran values, learning tools, integration

\section{Introduction}

The purpose of education is to instill good values and personality in the National Education System Act of 2003 Article 3. One of the schools to improve quality and education by using technology, to assist teachers in improving the learning process (Hanum, 2013). The use of technology is balanced with the concept of integrating Islam and science in learning as a solution to instill spiritual values in students (Winarti, 2015). Integrated learning and science can be applied in physics. Fusion of errors using the Quran in physics lessons so that students can apply and practice the contents of Al-Quran. The Qur'anic view of life in the world and life as a science.

Quran has principles that serve as a reference for generating theory and can be developed in the world of education (Sholichah, 2018). Ar Qurani (Al-Ibrah Qurani) is an innovative learning media of the Qur'an's exemplary story to create a generation of Quranic soul and strengthening character building in Indonesian children (Diana, 2017). This development produces learning media by integrating the science of Al-Quran with physics. Lexically, the term 'integration' is derived from the English integration of the integrate verb meaning to combine, integrate, unite, or integrate (Iskandar, 2016). The lexical meaning of this word integration can be interpreted as the incorporation or unification of some things into a solid unity and cannot be separated. The concept of integration of Qur'anic values in physics subjects has not been fully applied in the learning process in schools, especially in Islamic schools. There are so many spiritual values that can be cultivated in the study of physics is closely related to the concept of physics.

The concept can be run with the support of learning tools in accordance with the development of the 21st Century (Yusuf, 2016). The development of Science and Technology (IPTEK) resulted in changes in curriculum, media, and technology that teachers must balance out in making learning tools. Learning tools are made to support learning in the classroom so that students are active in learning. Every teacher in the educational unit is obliged to formulate a complete and systematic learning tool so that learning takes place interactively, inspiration, fun, challenging, motivate learners to participate actively, and provide sufficient space for students to develop activity, creativity, and independence in accordance with the talents, interests, and physical and psychological development of students (Sudarwati, et.al., 2016).

Current reality in the process of teaching and learning by instilling religious values that can link between science and religion is difficult to find (Badlisyah, 2017). Often each of these lessons runs independently and there is no relation to religion at all. This is because the assumption that religion only addresses the issue of worship only. The need for learning tools in the value of Al-Quran in the implementation of learning in the classroom. The purpose of this research is to develop physics learning device with integrity value qur'ani value, so that children can learn using modules that have integrated value of qurani in material of temperature physics and heat. 


\section{Method}

This research uses Research and Development (RND) research is a research process used to develop and validate research products (Borg \& Gall, 1983). The procedure in this study used 3-D model adapted from the development of 4-D model device (four D Model) as proposed (Thiagarajan, 1972). This model consists of 4 stages of development, namely Define, Design, Develop, and Disseminate.

Definition Stage (Define) which includes needs analysis, material analysis, and determination of learning resources. Needs analysis aims to establish and define the basic problems faced in learning. Material analysis and determination of learning resources aims to summarize the results of conceptual analysis to determine the basic capabilities of the research object. The second stage is the Design Phase which includes the selection of the format, the study of material literature, the initial design of modules and products. The selection of media formats aims to identify relevant learning media and determine the format in designing the product to be developed.

In this study developed is a learning device containing Quran value integration to instill spiritual values in students. Material literature studies are used to obtain an accurate source of material to be presented in the chase module. Furthermore, the manufacture of products in the form of syllabus, RPP, learning modules, and evaluation materials. The next stage of the Development Phase includes validation and revision, small-scale field trials and product revisions, large-scale field trials and end products.

The feasibility of a physics learning device using an analysis done by a lecturer of a material expert, an interconnection integration expert, a learning expert. The steps taken are the first step, changing the results of the assessment of material experts, media experts and physics teachers MA is still in the form of letters changed to the score in accordance with the Likert scale (Widoyoko, 2012).

The second step, calculating the average score of each aspect assessed by calculating the total score of all assessors' answers divided by the number of assessors multiplied by the number of answers. Third step, rat score appraisal application of physics learning device is changed to qualitative value based on assessment criteria table. This study used a scale of 4 then the table qualitative criteria shown as Table 1.

Table 1. Product Assessment Criteria

\begin{tabular}{cc}
\hline Average Score & Qualitative Criteria \\
\hline $3.25<\mathrm{X} \leq 4.00$ & Very good \\
$2.25<\mathrm{X} \leq 3.25$ & Good \\
$1.75<\mathrm{X} \leq 2.25$ & Less \\
$1.00<\mathrm{X} \leq 1.75$ & Very less \\
\hline
\end{tabular}

(Source: Widyoko, 2012:112)

\section{Results and Discussion}

This research develops product in the form of integrated physics learning device of Quranic value to instill analytical thinking of vocational students. As for the kinds of tools developed are syllabus, RPP, learning module and evaluation question. All learning tools have been validated by expert lecturers consisting of physics education experts, physicists and experts of value integration Qur'ani. Instrument validation is used to obtain the data provided by the evaluation expert. Development of learning tools using focus group discussions (FGDs) to identify what is needed in learning tools. Learning tools are developed to assist in learning the physics of vocational students.

Preparation of teaching material modules should have criteria and can improve student learning in the class (Chodijah, et.al., 2012). Therefore, the preparation of learning tools should be adjusted to the needs of students and teachers who teach in the classroom. If the learning device is not well structured and interesting then it cannot be used as teacher guidance in the implementation of learning. Reference in module development. Product assessment in the form of physics module containing integration of Qur'ani value to instill the spiritual values of vocational students conducted by lecturers physic education material experts, media experts, experts of Qur'ani value integration. The purpose of this product assessment is to know the quality of learning Qur'ani devices that have been made. In addition, product assessment also aims to get criticism and suggestions on learning tools that have been made. Data on assessment results learning tools that have been assessed by physics education materials experts, media experts and Islamic-science experts are as follows: 
Table 2. Expert appraisal Data Integration value of Qur'anic

\begin{tabular}{|c|c|c|c|c|c|c|c|c|}
\hline \multirow{2}{*}{$\begin{array}{c}\text { Aspect } \\
\text { Assesment }\end{array}$} & \multirow{2}{*}{$\begin{array}{c}\text { Criteria } \\
\text { Assesment }\end{array}$} & \multicolumn{3}{|c|}{ Assesment } & \multirow[t]{2}{*}{ Score } & \multirow{2}{*}{$\begin{array}{l}\text { Aspec } \\
\text { t score }\end{array}$} & \multirow[t]{2}{*}{ Average } & \multirow{2}{*}{$\begin{array}{c}\text { Categ } \\
\text { ory }\end{array}$} \\
\hline & & 1 & 2 & 3 & & & & \\
\hline \multirow{4}{*}{$\begin{array}{l}\text { 1. Quality } \\
\text { Aspects Of } \\
\text { Content }\end{array}$} & 1. Conformity of material with basic & 4 & 4 & 3 & 11 & 41 & 3.42 & $\begin{array}{l}\text { Very } \\
\text { good }\end{array}$ \\
\hline & $\begin{array}{l}\text { 2. Correctness of concepts as described by the } \\
\text { Physicist. }\end{array}$ & 4 & 3 & 4 & 1 & & & \\
\hline & $\begin{array}{l}\text { 3. There are images that can help students to } \\
\text { understand the material presented. }\end{array}$ & o & 3 & 3 & 9 & & & \\
\hline & $\begin{array}{l}\text { 4. There is a summary that includes the material } \\
\text { presented. }\end{array}$ & l & 4 & 3 & 10 & & & \\
\hline \multirow[t]{2}{*}{ 2. Language } & 1. There is no double sentence. & 4 & 3 & 3 & 10 & 21 & 3.5 & Very \\
\hline & $\begin{array}{l}\text { 2. Language used in accordance with the } \\
\text { development of student cognition and easy to } \\
\text { understand. }\end{array}$ & 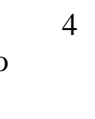 & 3 & 4 & 11 & & & \\
\hline \multirow[t]{3}{*}{ 3.Organization } & $\begin{array}{l}\text { 1. Material in the module is presented } \\
\text { systematically. }\end{array}$ & 3 & 4 & 3 & 11 & 21 & 3.5 & $\begin{array}{l}\text { Very } \\
\text { good }\end{array}$ \\
\hline & 2. Preparation of sub-chapters and inter & 4 & 3 & 4 & 10 & & & \\
\hline & paragraphs shows the demands. & 4 & 4 & 4 & 12 & 12 & 4.0 & Very \\
\hline \multicolumn{9}{|c|}{$\begin{array}{c}\text { 4. Truth of the } 1 . \begin{array}{l}\text { Conformity of concept with the concept } \\
\text { concept }\end{array} \text { presented }\end{array}$} \\
\hline Total Score & & 21 & 20 & 22 & 63 & 63 & 3.5 & $\begin{array}{l}\text { Very } \\
\text { good }\end{array}$ \\
\hline $\begin{array}{l}\text { Based } \\
\text { different sco } \\
\text { expert mater } \\
\text { results from } \\
\text { module inte } \\
\text { integration e } \\
\text { 3.5. So the } \\
\text { Assessment }\end{array}$ & $\begin{array}{l}\text { on Table } 2 \text { each aspect gets a } \\
\text { re with the highest score is } 4.0 \text { on } \\
\text { ial valuation data. In contrast to the } \\
\text { Table 3. On the assessment of the } \\
\text { rrelation with the Qurani value } \\
\text { xpert assessment all values indicate } \\
\text { categories that get very good. } \\
\text { of physics learning device product }\end{array}$ & \multicolumn{7}{|c|}{$\begin{array}{l}\text { with Quranic value integration to instill the } \\
\text { spiritual values of SMK students involves } \\
\text { several material experts. The material experts } \\
\text { are those who are experts in the field of physics } \\
\text { and physics education. It is intended to assess } \\
\text { whether the physics concepts in the integrated } \\
\text { heat physics module of Qur'anic values are } \\
\text { correct or no misconceptions occur. }\end{array}$} \\
\hline
\end{tabular}

Table 3. Expert Rating Data Integration of Qur'anic values

\begin{tabular}{|c|c|c|c|c|c|c|c|c|c|}
\hline \multirow{2}{*}{\multicolumn{2}{|c|}{$\begin{array}{c}\text { Aspect } \\
\text { Assesment }\end{array}$}} & \multirow{2}{*}{$\begin{array}{c}\text { Criteria } \\
\text { Assesment }\end{array}$} & \multicolumn{3}{|c|}{ Assesment } & \multirow[t]{2}{*}{ Score } & \multirow{2}{*}{$\begin{array}{l}\text { Aspect } \\
\text { Score }\end{array}$} & \multirow[t]{2}{*}{ Average } & \multirow[t]{2}{*}{ Category } \\
\hline & & & 1 & 2 & 3 & & & & \\
\hline \multirow[t]{2}{*}{1.} & $\begin{array}{l}\text { Aspect of } \\
\text { Integration } \\
\text { of Qur'anic }\end{array}$ & $\begin{array}{l}\text { 1. There are elements of } \\
\text { interrelation of Qur'an } \\
\text { science and physics. }\end{array}$ & 4 & 3 & 4 & 11 & 21 & 3.5 & Very good \\
\hline & Values & $\begin{array}{l}\text { 2. Conformity between the } \\
\text { Qur'an and the physics in } \\
\text { the module. }\end{array}$ & 3 & 3 & 4 & 10 & & & \\
\hline \multirow[t]{2}{*}{3.} & $\begin{array}{l}\text { Application } \\
\text { of Qur'anic } \\
\text { Value }\end{array}$ & $\begin{array}{l}\text { 1. There is a growing Qur'anic } \\
\text { value in the module to } \\
\text { improve analytic thinking in } \\
\text { students. }\end{array}$ & 3 & 4 & 4 & 11 & 21 & 3.5 & Very good \\
\hline & & $\begin{array}{l}\text { 2. There are problems that can } \\
\text { be analysed by the students. }\end{array}$ & 4 & 3 & 3 & 10 & & & \\
\hline \multirow[t]{3}{*}{3.} & $\begin{array}{l}\text { Usefulness } \\
\text { of Qur'anic } \\
\text { value }\end{array}$ & $\begin{array}{l}\text { 1. There is an example of } \\
\text { applying Qur'anic value } \\
\text { through practicum. }\end{array}$ & 4 & 4 & 3 & 11 & 21 & 3.5 & Very good \\
\hline & & $\begin{array}{l}\text { 2. There is an implementation } \\
\text { of integrated learning tools } \\
\text { Qur'anic value. }\end{array}$ & 3 & 3 & 4 & 10 & & & \\
\hline & Total Score & & 21 & 20 & 22 & 63 & 63 & 3.5 & $\begin{array}{l}\text { Very } \\
\text { good }\end{array}$ \\
\hline
\end{tabular}


The device is assessed by a material expert (physics) is a physics module with the concept of temperature and heat. The physics material developed in this module is related to the Qur'anic verses and there are Islamic values that can be picked and reflected on for students and students to think analytically after reading and working on sample questions. The samples are also a phenomenon of caloric-related daily phenomena by opening different paradigms of a physics concept, which describes Islamic values regarding the greatness of God and many other things. The following is a snapshot of the section of physics modules.

In general, the assessment of material experts, media experts, and teachers stated that this module is very good with all its advantages compared to existing physics modules or books that are used and used. For other Devices in the form of RPP and Syllabus material experts assess positive and good. In addition to providing a good assessment of the products that have been developed, the material expert also provides constructive criticism and suggestions on the product. As for the criticism and suggestion that is to reproduce the material in the module and RPP, the question of evaluation should be multiplied, for my experience activities in the module need to be developed new practice to broaden the knowledge of teacher and student and in add the argument of hadith that can strengthen Qur'an value in module.

When the concept of physics is associated with the Qur'anic verse in learning, students feel attracted by getting new things that have not previously been obtained. Begin to eliminate the view of those who doubt the link between the Qur'an and education related to the educational aspect (Nurhafizah, et.al., 2015). Based on field test found that students are very enthusiastic to follow the learning and become more want to know more about other physics concepts that can be associated with the verses of the Qur'an. This is in accordance with the opinions expressed by teachers during interviews that students will be very interested if there is a touch of verse and Islamic values in the study of physics interlocked in each other make students start to analyse a problem to get a solution. Makes students become more honed in their ability to think higher levels according to the 2013 curriculum.

\section{Conclusion}

The conclusion that can be taken in this development research is the development of learning tools with the integration of Qur'ani values in temperature and heat subject developed through R\&D research. The quality of instructional devices on temperature and caloric materials according to the physicist, physicist, and value integration expert Quran as a whole gives excellent value with the 3.5 category and the most prominent value in material conformity with the concept presented at provide it with a full value of 4.0. So it can be concluded from the assessment of the expert lecturers that the development of learning tools in the form of integrated module Qur'an value has been feasible to use and develop.

\section{References}

Hanum, Numiek Sulistyo. 2013. E-Learning Effectiveness as Learning Media (Study Evaluation of Learning Model ELearning SMK Telkom Shandy Putra Purworejo. Vocational Education Journals Vol. 3 No.1

Winarti. 2015. Development of Physical Learning Devices Laden with IslamScience Integration to Embed the Spiritual Values of Madrasah Aliyah Students. E-Journal.ikipmasiun. Vol 1 No. 2

Sholichah, Aas Siti. 2018. Educational Theories in the Qur'an. Journal of Islamic education. Vol. 07, No. 1

Diana, Risma Chulashotud. 2017. Ar Qurani (Al Ibrah Qurani): The Effort of Internalizing Qur'anic Values in Indonesian Muslim Children Based on the Koran Model Models Stories. National Seminar Education UNM, Malang

Iskandar, Syahrullah. 2016. Quran Study and Scientific Integration Case Study UIN Sunan Gunung Djati Bandung. Journal of Scientific Religion and Socio-Culture (86-93)

Yusuf, Irfan dkk. 2015. Development of Modern Physical Learning Devices Based on Virtual Media Laboratory Based on the 21st Century Learning Paradigm and the 
2013 curriculum. Lantanida Journal Vol. 5 No. 2.

Sudarwati,eta al. 2016. Development of Learning-Based Physics Learning Toolkit (PBL) on Newton's Legal Material and Its Application of Class x SMAN 2 Mejayan. Journal of Inquiry. Vol. 5 No. 3 (1-11).

Badlisyah, Teuku \& Wahyu Munawwwaroh. 2017. Development of Chemistry Learning Module of Al-Quran Based Atomic Structure In SMA N 1 Aceh Barat Daya. Journal of Lantanida Vo. 5 No.2 93-196

Borg, W.R. \& Gall, M.D. (1983). Educational research: an introduction. $4^{\text {th }}$ Edition. New York: Longman Inc.

Thiagarajan, Sivasailam, et.al., (1972). Instructional Development for
Training Teachers of Exceptional Children: A Sourcebook. Virginia: Association Drive, Reston.

Widoyoko, Eko Putro. (2012). Technique of Preparation of Research Instrument. Yogyakarta: Student Literature

Chodijah, Siti et.al., 2012. Development of Physics Learning Device Using Guide Model Inquiry Equipped with Portfolio Assessment on Circular Motion Material. Research Journal of Physics learning Vol. 1 (1-19).

Nurhafizah, et.al., 2015. Development of Physics Module of VII class of SMP / MTs based on Interrelation of AlQur'an and Science on Teaching Material. Periodic scientific journal of physics education. Vo. 3 no 1 (1-10). 